\title{
The Arrangement of Election Administration Organization In Law Number 7 Of 2017 Concerning Elections: Policy, Organizational And Political Analysis
}

\author{
Tatang Sudrajat ${ }^{1}$, Umi Rahmawati ${ }^{2}$, Hersusetiyati ${ }^{3}$, Tinda Irawati ${ }^{4}$ \\ Universitas Sangga Buana, Bandung, Indonesia ${ }^{1,3}$, Universitas Baturaja, Ogan Komering Ulu, \\ Indonesia ${ }^{2}$, Universitas Jenderal Achmad Yani, Cimahi, Indonesia ${ }^{4}$ \\ \{id.tatangsudrajat@gmail.com $\}$
}

\begin{abstract}
The arrangement of the election organizers in Law Number 7 of 2017, is something strategic for the development of democracy. From the aspect of public interest contained in it, the law is basically a public policy. The General Election Commission (KPU), the Election Supervisory Body (Bawaslu) and the Election Organizing Honorary Council (DKPP) are both designated as election organizers, in their organizational arrangements there are differences. With normative juridical research methods and literature, it appears that as a product of public policy, this law has regulated several organizational dimensions, and must be followed up with more operational policies. The arrangement of the KPU's organizational dimensions is more than that of Bawaslu and DKPP. The arrangement of the organizational dimensions of DKPP is the least compared to KPU and Bawaslu. There are inconsistent and incomplete arrangements of several organizational dimensions, as well as arrangements for different organizational characteristics among the three election management bodies. From the political aspect, the organization of Bawaslu and DKPP is more complete than that regulated in the previous law, adding to the weight of both institutionally. It is necessary to rearrange the organizational dimensions of the three institutions in a more proportional manner.
\end{abstract}

Keywords : election management, analysis, organization, policy, politics.

\section{Introduction}

In the implementation of elections, the regulation of election organizers in the election law or the law that specifically regulates election organizers is very important. Since Indonesia's independence until now, there has been a special regulation in a separate law, namely Law Number 22 of 2011 concerning Election Organizers [1]. In Article 1 point 7 it is stated that the election organizer is an institution that organizes elections consisting of the General Election Commission (KPU), the Election Supervisory Body, and the Election Organizing Honorary Council (DKPP) as a unitary function of organizing elections to elect members of the DPR, members of the DPD, President and Vice President, and to elect members of DPRD directly by the people. Since then, the term election organizer is an integral part of any discussion on elections.

The issuance of Law Number 7 of 2017 concerning Elections [2] is an important step in simplifying election arrangements, at least it has combined the three electoral laws that were previously in force. Although this law does not specifically regulate election management, the regulation is quite adequate. The number of articles is 160 out of a total of 573 articles (27.9\%), 
so this is a strategic aspect for furthermore operational arrangements regarding various aspects of the organization as an election organizer. From the perspective of the duties and authorities as well as the people who work together in these three institutions, it is clear that the election organizer is an organization.

Adequate regulation of various aspects of the organization as an election organizer in the laws governing it is an important factor for the success of the election. Clarity about institutional status in the government structure, duties and authorities, as well as structural relationships between election organizers, will facilitate overall election activities. The potential for conflicts between institutions will also be reduced, because there are the same interpretations of election stakeholders regarding organizational arrangements.

Harmonious relations between election management institutions are very important for efforts to create a political order at the level of the political superstructure. For example, between Bawaslu as the supervisor of the election administration and the KPU as the highest institution in the structure of the election implementation, at the national and regional levels, it is often seen that the organizational relationship is not harmonious. Bawaslu seems like an institution that deliberately only finds fault with the KPU, even though this is considered something that is not basic by the KPU.

From the perspective of the public interest, the existence of provisions in the law regarding various aspects of the organization of election management which reflects the guarantee of the implementation of democratic elections, is basically a public policy. Because, the public's hope is on these three institutions to be able to carry out their duties and authorities effectively in accordance with the provisions of the law, so that they will contribute positively to the strength of Indonesia as a democratic state.

This study aims to analyze from the policy, organizational and political aspects of the organizational arrangements of the election management bodies in Law Number 7 of 2017.

\section{Literature Review}

\subsection{Election}

The discussion about the organization which is an election management body will be related to the discourse of democracy. Henry B. Mayo argued that democracy is based on several values, the manifestation of which is highly dependent on the historical development and political culture of each country. Some of them are institutionalized peaceful settlement of conflict, peaceful changes in a changing society, and organizing regular succession of rules [3].

To implement democratic values, according to Budiardjo, several institutions need to be held including, as well as a people's representative council that represents various groups and interests in society who are elected in elections, conduct supervision, allow constructive opposition, and allow continuous assessment of government policies [3]. According to Michael, there are several key elements of democracy, namely recognition of rights for individuals, consent of the people, accountability of decision makers to the people, representation, and formal processes to demarcate and limit the role of decision makers [4].

There are several special institutions that affirm the regime of a democratic state, including the control over government decisions on policies that are constitutionally borne by elected officials; the elected officials always come from an honest election process, practically all adults have the right to choose official officials; and practically all adults have the right to be elected as official in government, although the age limit for election may be higher than the age limit for voting [5]. 
According to Michael, the characteristics of democratic government include the principle of representation---the people who are subject to the laws must be equally represented in the legislative process that makes those laws; and the institutionalization of the process of government -in which functions are delineated, responsibilities are defined, and the mechanisms for change, including elections, are prescribed [4].

According to Affan Gaffar, there are several indicators or measures to see whether or not a country's political life is democratic, one of which is general elections. General elections are held regularly with clear deadlines, or as needed. Every citizen who has been allowed by the applicable provisions to vote has the right to vote and be elected, and is free to use that right according to the call of his conscience or according to the calculation of his interests rationally $[6]$.

In addition, in political and government practice, the term Indonesian Democracy Index (IDI) is also known as a certain number that indicates the level of development and implementation of democracy, both in Indonesia as a whole and in each province. This IDI consists of three dimensions, namely Civil Liberties, Political Rights, and Democratic Institutions. Aspects of political rights in accordance with the IDI consist of the right to vote and be elected; and political participation in decision-making and oversight. Aspects of Democratic Institutions, including free and fair elections.

\subsection{Policy and Politics}

Public policy regarding the implementation of elections certainly cannot be separated from public administration. Public administration according to Dwight Waldo is the organization and management of man and material to achieve the purpose of government [7]. The discussion on the existence of public administration will of course also discuss the existence and performance of the state and/or government. Public administration is very important in the existence and achievement of state goals. The role of public policy will give its own colour and label to the public administration of a country.

Various parties from public administration studies have called this public policy one of the prime dimensions of state administration. According to Keban, this policy is one of the strategic aspects or dimensions of the six strategic dimensions or the one that most determines the dynamics of public administration, namely in the form of responding correctly to the needs, interests and aspirations of the community in the form of decision making or public policy [8]. So, it can be said that public policy is the dynamics of state administration. It can also be understood when some public administration experts define public administration as a process for implementing public policy.

Communities in various parts of the world in reality face various problems that they cannot always solve on their own. The next phase then becomes a broad public concern, is discussed and becomes the focus of the government's agenda, then through a series of political and/or administrative processes it is decided and followed by actual actions for the public interest, then public policy is born. According to Gerston, public policy is the combination of basic decisions, commitments, and actions made by those who hold or influence government positions of authority [9]. Posts et al. put it forward as a plan of action undertaken by government officials to achieve some broad purpose affecting a substantial segment of a nation's citizens [10].

Another expert, Dunn with his point of view as the government's choice, defines public policy as a long series or more less related choices (including decisions not to act) made by governmental bodies and officials, are formulated in issue areas which range from defense, energy and health to education, welfare and crime control [11]. 
MacRae Jr. and Wilde defines it as a policy made by government. Policy is a chosen course of significantly affecting large numbers of people [12]. Another public policy scientist said that public policies are those policies developed by governmental bodies and officials. Nongovernmental actors and factors may, of course, influence policy development [13]. It appears that the state or government is very strategic in the formation of this public policy. This is in line with Michael's view that without the existence of the state, the public policy making process, as we know it, could not operate. It is the state that provides the basis for collective decision making, the application and enforcement of those decisions, and the means for changing or altering others [4].

In the study of public policy, there are five components, namely issues, actors, resources, institutions and the level of government. It was further stated that issues that appear on the public agenda; actors who present, interpret, and respond to those issues; resources affected by those issues; institutions that deal with issues; and the levels of government that address issues [9]. For those who intend to study public policy more comprehensively, the integral can be identified as policy categories, namely policy demands, policy decisions, policy statements, policy outputs and policy outcomes [13].

In relation to the expectations and interests of the public for the realization of increasingly high-quality elections, public policy is a series of decisions made by state/government officials and/or institutions that previously involved various parties, followed by concrete actions in accordance with the authority they have to handle various aspects of election administration.

\section{Organization}

The discussion about the election management bodies will not be separated from the academic discussion about the organization. According to Robbins, the organization is a consciously coordinated social entity, with a relatively identifiable boundary, that functions on a relatively continuous basis to achieve a common goal or set of goals [14]. Narayanan and Nath [15] define it as an arena where human beings come together to perform complex tasks so as to fulfill common goal(s). Other experts refer to the organization as the structuring of individuals and functions into productive relationships. Organization seeks a pattern of skills and responsibilities that will ensure coordination and unity of purpose through supervision [16].

Theoretically, the organizational dimension according to Daft consists of a structural dimension and a contextual dimension. According to him, the structural dimensions provide labels to describe the internal characteristics of an organization. They create a basis for measuring and comparing organizations. It was further stated that the structural dimensions consist of specialization, hierarchy of authority, professionalism, and personnel ratios. Furthermore, it is stated that contextual dimensions characterize the whole organization. Among them are size, and goals. They describe the organizational setting that influences the structural dimensions [17].

Each structural dimension is explained by Daft [17] that specialization is the degree to which organizational tasks are subdivided into separate jobs. The hierarchy of authority describes who reports to whom and the span of control for each manager. Professionalism is the level of formal education and training of employees. Professionalism is considered high when employees require long periods of training to hold jobs in the organization. Personnel ratios refer to the deployment of people to various functions and departments [17]. Next, he explained the contextual dimensions, among others, that Size is the organization's magnitude as reflected in the number of people in the organization. Goals are often written down as an enduring 
statement of company intent. The environment includes all elements outside the boundary of the organization [17].

Based on Daft's view it appears that an analysis of these several organizational dimensions is very important to understand the complete posture of the organization. During their life, humans will find various types of organizations. Talcot Parsons suggests that there are four types of organizations, namely production organizations, political organizations, integrative organizations, and pattern maintenance organizations. It was further stated that political organization is concerned with ensuring that society as a whole achieves its objectives [15].

\section{Research Methods}

This research uses a combination of normative juridical research and literature study. According to Marzuki, it is classified as legal research [18], or normative legal research or library law which is carried out by examining library materials or secondary data [19]. Based on the level of explanation, this research is a descriptive research. One type of descriptive research is library and documentary research [20].

Literature research or literature study is a series of activities related to the methods of collecting library data, reading and recording and processing research materials [21]. In accordance with the research objective to assess the substance of the policy, this research includes policy research. One type of policy analysis is studies of policy content, in which analysis seek to describe an explain the genesis and development of particular policies [22]. Research is conducted on information that is documented in the form of regulations so that it is commonly known as document analysis research or content analysis. The document that is the focus of the study is Law Number 17 of 2017 [2], as well as various other sources in the form of books and journals that are relevant to the research topic.

\section{Results and Discussion}

\subsection{Policy Analysis}

The substance contained in Law Number 7 of 2017 [2] can be referred to as public policy, because some of the things it regulates are related to the broad public interest, including elections that are fair and with integrity. Elections with such characteristics are a manifestation of a democratic state as a vehicle for the people to express their political will. This is in line with what Wilde stated that a policy is made by government. Policy is a chosen course of significantly affecting large numbers of people [23].

Referring to Anderson that in its positive form, public policy based on law, therefore the public interest, which among others relates to the posture of election organizers, is regulated in Law Number 7 of 2017 [2] which was ratified on August 15, 2017. Based on Anderson's opinion, this is a category of policy called policy decisions, namely are decisions made by public officials that authorize or give direction and content to public policy actions [13]. With the enactment of this Law which consists of 573 articles, the three laws are no longer valid.

The three are Law Number 42 of 2008 concerning Presidential and Vice Presidential Elections [24], Law Number 22 of 2011 concerning Election Organizers [1], and Law Number 8 of 2012 concerning Elections for Members of DPR, DPD and DPRD [25]. In addition, Article 57 and Article 60 paragraph (1), paragraph (2) and paragraph (4) of Law Number 11 of 2006 concerning the Government of Aceh [26] are no longer applicable. The provisions regarding 
KPU are contained in Articles 6 to 88 (82 articles), about Bawaslu in Articles 89 to 154 (55 articles), and DKPP starting from Articles 155 to 166 (11 articles).

As the final product of the political process, the issuance of this law is a joint agreement between the DPR and the President and his staff. Following the opinion of [9] and Howlett and Ramesh [27], they are policy actors. The involvement of state/government officials as policy actors in the state/government domain when setting policies for the implementation of this election is part of the institutional arrangement that shows the connection between the actors involved. Howlett and Ramesh mention that policies are made by policy subsystems consisting of actors deaking with a public problem. Policy subsystems are forums where actors discuss policy issues and persuade and bargain in pursuit of their interests. These interactions, however, occur in the context of various institutional arrangements surrounding the policy process and affecting how the actors pursue their interests and ideas and the extent to which their efforts succeed [27].

In line with Anderson's opinion that one of the characteristics of the concept of public policy is purposive or goal oriented action rather than random or chance behavior is our concern [13], the purpose of regulating the election administration as referred to in Article 4 is to strengthen a democratic state administration system, realizing elections that are fair and with integrity, ensuring consistency in the regulation of the electoral system, providing legal certainty and preventing duplication in election arrangements, and realizing effective and efficient elections.

Public expectations of election organizers to be able to appear as a solid supporter of a democratic state, cannot be separated from the implementation of state functions in general. This is in line with the long-term development direction of 2005-2025 as stated in Law No. 17 of 2007 concerning the 2005-2025 Long-Term Development Plan [28], which among other things states that in order to realize a democratic Indonesia based on law, among others, is to improve the performance of implementing institutions. the state in carrying out the authorities and functions conferred by the constitution and laws and regulations, as well as creating further democratic institutions to support the ongoing consolidation of democracy in a sustainable manner.

Election organizers as organizations in the regulation of this law are also related to the terms "election administration" and "election implementation" which seem to overlap. From the perspective of public policy evaluation, referring to Hill [22], it is very important and strategic to evaluate the substance of the policy, because it is important for effective policy implementation. The success of a public policy implementation, according to Muchsin and Fadillah Putera, is also highly dependent on the quality of the substance of the legal product or law. If the quality of the law or legal product is low, the success rate of the public policy implementation process will be low. On the other hand, if the substance of the law is of high quality, the quality of the existing public policy implementation process will also be high [29]. Thus, terminology clarity is also very important for the implementation of their respective duties and authorities as elements of the election organizers.

The implementation of elections according to Article 1 number 2 is the stages of elections carried out by election organizers. This is ambiguous when it is associated with the phrase in Article 1 number 7 which states that "election organizers are institutions that organize elections...". This ambiguity and terminology inconsistency also appears to be related to the phrase in Article 1 point 8 that the KPU is an "election organizing body....in carrying out elections". It also appears in the phrase Article 1 number 17 which states that Bawaslu is an election management agency that oversees the implementation of elections...". In other words, there is a terminological confusion between Article 1 point 2 and Article 1 point 7, Article 1 point 8 , and Article 1 point 17. 
Likewise, there are terminological inconsistencies in the substance of this policy regarding the term "institution" which is contained in Article 1 number 24 that DKPP is an institution tasked with handling violations of the code of ethics for election administrators. It should be consistent with the provisions of Article 1 point 7, number 8, and number 17, the term attached to DKPP is as an "election organizing institution", not only as an "institution". Because it is definitively based on the provisions of Article 1 point 7 it is very clear that the KPU, Bawaslu and DKPP are respectively referred to as elements of the election management body.

The phrase "one unitary function of the election administration" as referred to in Article 1 point 7 which consists of KPU, Bawaslu and DKPP as election management institutions, also creates confusion, for example when it is associated with the provisions of Article 1 number 17 regarding Bawaslu. Bawaslu, which, according to Article 1 point 17, oversees the implementation of elections, is ambiguous because Bawaslu itself is an election management body. The implementation of elections according to Article 1 point 2 is the implementation of the stages of the election carried out by election organizers, which according to Article 1 point 7 Bawaslu is also an election organizing body.

The term "election management institution" should be changed to only "election institution" or "institution", which by definition the three elements of "electoral institution" or "institution" each have specific tasks and do not overlap in terms of terminology. Thus, the KPU should be the institution that carries out the elections, the Bawaslu as the institution that oversees the implementation of the election, and the DKPP as the institution that enforces the election code of ethics.

\subsection{Organizational Analysis}

The organizational dimensions refer to Daft, among them are hierarchy of authority, specialization, size, goals, standardization, formalization [17]. Provisions in Law Number 7 of 2017 which regulate various aspects of the organization as an election organizer starting from Article 6 to Article 166. The first institution to be regulated is the KPU, which according to Article 1 point 8 is an election management body that is national, permanent and independent in conducting elections. The KPU referred to in the provision, according to Article 6 consists of KPU, Provincial KPU, Regency/Municipal KPU, PPK, PPS, PPLN, KPPS, and KPPLN. In other words, there is an inconsistency between the provisions of Article 1 point 8 and those contained in Article 6.

The provisions of Article 10 paragraph (4) that the KPU Chair is elected from and by members, as well as paragraph (5) which states that each KPU member has the same voting rights, are important matters regarding the characteristics of a collegial KPU organizational leadership. This is in line with the provisions regarding the decision-making mechanism regulated in Articles 40 to 47. This regulation is a preventive measure against the possibility of an unhealthy organizational rhythm due to the dominant figure of the KPU Chairperson in decision-making. Because the process related to this election will have implications for the public interest if it is not carried out based on organizational rules. Daft suggests that organizational decision making is formally defined as the process of identifying and solving problems. The problem identification stage and the problem solution stage [17].

The continuous implementation of KPU duties as referred to in Article 7 paragraph (2) is not in line with the provisions governing PPK, PPS, PPLN, KPPS and KPPLN whose term of office is only for a certain period of time before and during the election. This is different from KPU, Provincial KPU and Regency/Municipal KPU which according to Article 9 paragraph (2) are permanent. In other words, the provisions of Article 6 are not in line with Article 7 paragraph (2) and Article 9 paragraph (2). 
According to Article 8 paragraph (4), KPU, Provincial KPU and Regency/Municipal KPU are non-structural institutions. According to the Elucidation of the Article, this institution is an institution formed because of the urgency of a certain special task that cannot be accommodated in the form of a government/state institution. Non-structural institutions according to the State Administration Institute [30] are independent institutions established by law to carry out certain tasks which due to the nature of their duties cannot be contained in the form of existing ministries/institutions, where institutional membership involves elements outside government and its existence is funded by the state budget. However, the same position as a non-structural institution is not mentioned in Bawaslu (Article 89 to Article 54) and DKPP (Article 155 to Article 166) which are both election organizers. In fact, Bawaslu and DKPP should also have a clear designation of institutional position as a non-structural institution or other relevant designations.

The institutional affirmation of KPU, Provincial KPU and Regency/Municipal KPU as permanent, not ad hoc is contained in Article 9 paragraph (2), as for Bawaslu, Provincial Bawaslu, and Regency/Municipal Bawaslu in Article 89 paragraph (4). There is an incomplete regulation that the PPK and its subordinate institutions as institutions are not permanent or ad hoc, which is different from the Panwascam and its subordinate institutions which are referred to as ad hoc in Article 89 paragraph (5). Affirmation as an organization that is permanent or ad hoc is very important when elections are in the implementation stage. As a fellow institution/committee formed with the same nature and position, the PPK and its subordinate institutions/committees should consistently act as ad hoc.

The hierarchical organizational relationship between KPU, Provincial KPU and Regency/Municipal KPU is regulated in Article 9 paragraph (1), but the nature of the same relationship is not mentioned in the PPK institution and the institutions below it. In fact, this hierarchical relationship is fully regulated in election supervisory institutions starting from Bawaslu to supervisors at the lowest level as referred to in Article 89 paragraph (3). The affirmation of this organizational hierarchical relationship is very important, among others, for the realization of the administrative principles proposed by Henry Fayol, including unity of direction, centralization and unity of command [14].

The regulation of the duties, authorities and obligations of each element of the implementing agency is very important to achieve maximum organizational performance. This includes, among others, what is stated in Article 7 paragraph (2), Article 11, and Article 12 concerning the duties of the KPU/Chairman of the KPU, Article 13 concerning the authority of the KPU, and Article 14 concerning the obligations of the KPU. In addition, it is regulated in Article 93 and Article 94 regarding the duties of Bawaslu, Article 95 concerning the authority of Bawaslu, and Article 96 concerning the obligations of Bawaslu, as well as in Article 159 for the duties, powers and obligations of the DKPP.

To carry out its duties and functions, an organization will be equipped with authority and responsibility as one of the general principles of organization and administration as stated by Henry Fayol which was emphasized by Robbins that managers need to be able to give orders. Authority gives them this right. Along with authority, however, goes responsibility. Whereever authority exercised, responsibility arises. To be effective, a manager's authority must equal his or her responsibility [14]. In the context of state organizations more broadly, this is also related to the authority regulated in 5 Law Number 30 of 2014 concerning Government Administration [31]. According to Article 1 point 5 authority is the right owned by government agencies and/or officials or other state administrators to take decisions and/or actions in the administration of government. 
The provisions of Article 6 regarding the KPU are contradictory to the provisions of Article 1 point 8 . The contradiction lies in the KPU as referred to in Article 1 point 8 with the KPU as referred to in Article 6 letter a, because there is uncertainty regarding the similarities or differences in the term "KPU" in the two provisions. This contradiction is also seen in relation to the term "permanent" attached to the KPU institution in Article 1 point 8, which is contradictory to the existence of the PPK and the institutions/committees under it as referred to in Article 6 which are not permanent.

This contradiction is also attached to the existence of PPK, PPS, and PPLN which in Article 1 points 11,12 , and 13 all use the term "committee", which is associated with the provisions of Article 1 point 8 and Article 6 precisely as part of the election organizer, as attached at the Provincial KPU and Regency/Municipal KPU. Likewise, the term "group" attached to KPPS and KPPSLN creates ambiguity in relation to the terms "organizing institution" and "committee". The terms or phrases attached to these three elements of election management should be referred to as "ad hoc institutions in charge of carrying out elections at the sub-district, village/kelurahan level, abroad". KPPS/KPPLN are referred to as "ad hoc institutions in charge of carrying out voting at overseas TPS/TPS". This contradiction is also found in Article 1 number 17 regarding the term "Bawaslu" with that contained in Article 89 paragraph (2) letter a.

The aspect of organizational professionalism can be seen in the regulation of educational qualification requirements that must be met when a person becomes a member of the KPU, namely Article 21 paragraph (1) f, that the minimum is strata 1 (S-1). The same thing for Bawaslu is regulated in Article 117 paragraph (1) letter $\mathrm{f}$, while for DKPP members this is not regulated, especially five people who come from elements of the community as referred to in Article 155 paragraph (4) letter c. However, there is no clarity about the specific fields of knowledge that must be fulfilled by candidates for KPU and Bawaslu members. Because the Elucidation of Article 21 paragraph (1) letter e only states that candidate members are prioritized to have the ability to conduct elections, both in the fields of political science, law and management.

In addition, having knowledge and expertise related to the administration of elections, state administration, and parties, as evidenced by going through a series of tests. There should be specific educational requirements, such as the requirements to become a member of the Corruption Eradication Commission as regulated in Article 29 letter d of Law Number 30 of 2002 concerning the Corruption Eradication Commission and the State Civil Apparatus Commission [32] in Article 38 paragraph (2) letter g of Law Number 52014 concerning Civil Apparatus State [33].

The duties of the Chairperson of the KPU are regulated in Article 11 paragraph (1) which mutatis mutandis also applies to the Chairperson of the Provincial KPU and the Chairperson of the Regency/Municipal KPU. The regulation regarding the duties of the chairman as the head of the organization is very important so that there is clarity regarding the boundaries and differences between the duties of the KPU institutionally as regulated in Article 12. Likewise, the regulation on the authority and obligations of the KPU institutionally as stated in Article 13 and Article 14.

However, the duties of the Chairperson are Bawaslu and the Chairperson of DKPP are not listed in this law, even though as fellow election management institutions they have an organizational element named the Chairperson as stipulated in Article 92 paragraph (7) and Article 156 paragraph (1). Whereas the duties, authorities and obligations are explicitly regulated in Articles 93 to 96 for Bawaslu, and Article 159 for DKPP. Arrangements regarding the duties, authorities and obligations of each element of the organization differently are very 
important to ensure the running of the organization in accordance with the objectives of its establishment. In this regard, Robbins argues that differentiation as the number of specialty functions is represented in a firm or the difference in cognitive and emotional orientation among managers in different departments [14].

In relation to the ethics of state administration, the existence of DKPP as an institution that enforces the code of ethics for election organizers is very strategic, because it relates to public expectations for the appearance of an election organizer with integrity.The presence of TAP MPR Number VI/MPR/2001 concerning the Ethics of National Life is essential because it can be a reference for the government and the entire Indonesian nation in order to save and improve the quality of life for the nation. One of them is ethics in politics and government.

The provisions of Article 155 paragraph (4) letters a and b which state that DKPP consists of 1 (one) ex officio from the KPU element and 1 (one) person from the Bawaslu element, is a matter that has the potential to disrupt the integrity of its institutions as enforcers of the code of ethics for the election organizers. It is not easy for the two members of the seven members of the DKPP when they have to carry out a trial to examine allegations of violations of the code of ethics committed by elements of the election organizers who come from the same element as the institution.

There is a big challenge for both of them to appear as enforcers of the code of ethics in a professional, proportional and fair manner, which is different from the challenges for the other five members of DKPP which according to Article 155 paragraph (4) letter c comes from community leaders. According to the explanation of the article, community leaders are academics or figures who have vision, integrity, and understand the ethics of organizing elections.

The existence of KPU Regulations, Bawaslu Regulations and DKPP Regulations is very important as respectively regulated in Article 75, Article 145 and Article 160, only these provisions do not state that they are formed in carrying out the duties, authorities and obligations of each institution as stipulated in law. Organizationally this is very important because it relates to the regulation of standards and activities in the form of formalization and standardization in accordance with their area of authority as election organizers. In this context, Daft stated that formalization pertains to the amount of written documentation in the organization documentation includes procedures, job descriptions, regulations, and policy manuals. Standardization is the extent to which similar work activities are performed in a uniform manner [17].

The regulation of reporting and accountability aspects is important in the organization, especially with regard to the reputation as a democratic country and the management of a very large state budget. Article 48 paragraph (1) letter a state that the KPU in carrying out its duties carries out financial accountability in accordance with the provisions of the legislation. In addition, Article 48 paragraph (1) letter b states that the KPU reports to the DPR and the President regarding the implementation of the tasks of organizing all stages of the election and other tasks.

The regulation of the number of members of the organization is very important for the smooth implementation of duties, authorities and obligations. This is regulated in Article 10 for KPU, Article 92 for Bawaslu, and Article 155 for DKPP. Likewise, it is appropriate to regulate the number of members that are not uniform for the Provincial KPU, Regency/Municipal KPU, Provincial Bawaslu, and Regency/City Bawaslu but are proportional based on the population and working area area. This is regulated in Article 10 paragraph (1) letter b and letter c, Article 92 paragraph (91) letter b and letter c. 
The existence of the secretariat element as an element of the support staff and the operating core of election organizers is very important to regulate in the law. As an element that supports and facilitates the KPU, the existence of the General KPU Secretariat is regulated in Articles 78 to 86. As an organizational element that supports the smooth running of Bawaslu duties and authorities, the existence of the Bawaslu General Secretariat is regulated in Articles 147 to 154. DKPP in carrying out its duties and authorities is supported by the DKPP Secretariat as regulated in Article 163 to Article 166.

The existence of this secretariat is very strategic for organizational performance. This is because it relates to its role as the operating core and the support staff of the KPU, Bawaslu and DKPP organizations. Henry Mintzberg as quoted by Robbins suggests that the operating core as employees who perform the basic work related to the production of products and services. The support staff as people who fill the staff unit, who provide indirect support services for the organization [34]. This is in line with Siagian's opinion about the existence of two groups of employees, namely those whose main task is to carry out activities that are translating main tasks into activities, and those whose duties are to carry out supporting activities for the smooth running of the wheels and organizational mechanisms [35].

\subsection{Political Analysis}

Based on the duties, authorities, and obligations attached to these three organizing institutions, KPU, Bawaslu and DKPP are political organizations, according to Talcot Parsons that political organizations are concerned with ensuring that society as a whole achieves its objectives [15]. In the political context, the regulation of the authority of the three election management bodies very important to ensure that their duties and functions can be carried out effectively. According to Surbakti, authority is power. However, power is not always in the form of authority, because authority is legitimate power, while power does not always have legitimacy. Authority is a moral right to make and implement political decisions. In this case, moral rights are in accordance with the values and norms of society, including laws and regulations [36].

The independence of election organizers is very essential for the realization of fair elections and with integrity as referred to in Article 4. Politically, the provisions in the law concerning the obligation to be free from any influence, are a fundamental aspect for the appearance of an independent, impartial, neutral election organizer. and integrity. The independent characteristics of the KPU are stated in Article 7 paragraph (3), but the same is not contained in the arrangements for Bawaslu (Article 89 to Article 154) and DKPP (Article 155 to 166). As a fellow election organizer as mentioned in Article 1 point 7 , this should also be explicitly regulated. This affirmation is very important, because from a political perspective, the presence of an independent organizing agency is an absolute and non-negotiable requirement. This independence according to Harianti et al. demands three things, namely institutional independence, functional independence, and personal independence [37].

Politically, the mention of the term "independent" (Article 1 point 8) in general for election organizers, as well as the phrase "free from the influence of any party" (Article 7 paragraph (3) specifically for KPU institutions are very important to ensure that as an organization that is not only capable, but also credible and with integrity. But the phrase "free from the influence of any party" is not regulated in the provisions regarding Bawaslu (Articles 89 to 154) and DKPP (Articles 155 to 166). In fact, the affirmation in the law regarding the characteristics of such an organization will be very supportive of the efforts to create an election management organization that is at the same time accountable and acceptable. 
Politically, the performance of all elements of election management will greatly contribute to the image of Indonesia as a democratic state as a whole. In Ardipandanto's view, the idealism of holding simultaneous elections in 2019 has not been matched by the strength and ability of election organizers and the lack of strong awareness that changes in electoral systems and techniques require extraordinary capabilities and professionalism of organizers [38]. Likewise, the challenge for Bawaslu down to the lowest level is to achieve maximum performance. The impression that as an institution that only looks for faults so as to marginalize objectivity in carrying out its duties, functions, authorities and obligations, must be proven by the performance of all Bawaslu components that make the public proud. Puspitasari's research shows that organizational commitment, work ethic and team work have a positive and significant effect on Bawaslu's performance [39].

Politically, from time to time, the challenge for the presence of an election management body that is independent and with integrity is getting bigger. There have been many KPU and Bawaslu officials at the central to regional levels, who have been involved in legal cases or codes of ethics, so that some of them have to serve sentences and end their careers as part of election organizers. The very strong interaction of election administrators with various components of political power, especially political parties, including those currently holding power at various levels of government, confronts them with various temptations that can lead them astray.

In this context, DKPP Regulation Number 2 of 2017 concerning the Code of Ethics for Election Organizers is a very strategic matter to fortify each election management apparatus from potential ethical and moral violations. As an integral part of state administration in a broad sense, Keban mentions that moral ethics is one of the six strategic dimensions of public administration [8]. For the presence of the KPU and Bawaslu and their staff to the lowest level, the role of DKPP as a guardian of ethics and morals is very strategic but cannot be separated from various challenges. The challenges, according to Gusfa et al. include the view that there is no need for DKPP [40], so that there is no other way for DKPP except to improve its performance in enforcing the code of ethics for election organizers.

\section{Conclusion}

The presence of Law Number 7 of 2017 is an important aspect for regulating election management organizations. From the perspective of the public interest, this is a public policy because it contains the hope of the appearance of a capable and integrity election organizer. Politically, the regulation on the nature of independence as an election management body requires the KPU, Bawaslu and DKPP to face greater challenges. Several organizational dimensions have been regulated in the law, including specialization, hierarchy of authority, formalization, standardization, and organizational size. There are several arrangements for organizational dimensions that are incomplete, contradictory and inconsistent. It is necessary to refine several organizational provisions for an effective organization to appear.

\section{References}

[1] "UU Nomor 22 Tahun 2011 tentang Penyelenggara Pemilu."

[2] "UU Nomor 7 Tahun 2017 tentang Pemilu."

[3] Budiardjo, M. Dasar-dasar Ilmu Politik, Edisi Revisi. Jakarta: PT. Gramedia Pustaka Utama, 2008. 
[4] Michael, E. J. Public Policy: The Competitive Framework. South Melbourne: Oxford University Press, 2006.

[5] Dahl, R. A. Dilema Demokrasi Pluralis. Antara Otonomi dan Kontrol (Penerjemah: Sahat Simamora). Jakarta: PT. Rajawali, 1985.

[6] Taher, E. P. Demokratisasi Politik, Budaya dan Ekonomi. Pengalaman Indonesia di Masa Orde Baru. Jakarta: Yayasan Paramadina, 1994.

[7] Rosenbloom D. Contemporary Public Administration. New York: McGraw-Hill. Inc., 1994.

[8] Keban, Y. T. Enam Dimensi Strategis Administrasi Publik. Konsep, Teori dan Isu. Yogyakarta: Gaya Media, 2004.

[9] Gerston, L. N. Public Policy Making. Process and Principles. Third Edition. New York: E Sharpe, 2010.

[10] Post, J. E. et al. Business and Society. Corporate Strategy, Public Policy, Ethics. Boston: Irwin McGraw-Hill, 1999.

[11] Dunn, W. N. Public Policy Analysis : An Introduction. London: Prentice-Hall International, Inc, 1981.

[12] MacRae Jr. D. and W. James, Policy Analysis for Public Decisions. New York: University Press of America, 1989.

[13] Anderson, J. E. Public Policy-Making, Second Edition. New York: Holt, Rinehart and Winston, 1978.

[14] Robbins, S. P. Organization Theory : Structure, Design, and Applications, Third Edition. Englewood Clifft New Jersey: Prentice-Hall International, Inc, 1990.

[15] Narayanan V. and N. R, Organization Theory. A Strategic Approach. Homewood IL Boston: Richard D. Irwin Inc., 1993.

[16] Pfiffner J. and R. P, Public Administration. New York: Ronald Press, 1960.

[17] Daft, R. Organization Theory and Design. Fourth Edition. Singapore: Info Access Distribution Pte Ltd, 1992.

[18] Marzuki, P. M. Penelitian Hukum, Edisi Revisi. Jakarta: Prenadamedia Group, 2015.

[19] Soekanto S. and S. Mamudji, Penelitian Hukum Normatif. Suatu Tinjauan Singkat. Jakarta: PT RajaGrafindo Persada, 2015.

[20] Nazir, M. Metode Penelitian. Bogor: Ghalia Indonesia, 2011.

[21] Zed, M. Metode Penelitian Kepustakaan. Jakarta: Yayasan Obor Indonesia, 2004.

[22] Hill, M. The Policy Process in the Modern State, Third Edition. London: Prentice-Hall International, Inc, 1997.

[23] Wilde, J. Policy Analysis for Public Decisions. Lanham: University Press of America, 1985.

[24] "UU Nomor 42 Tahun 2008 tentang Pemilu Presiden dan Wakil Presiden."

[25] "UU Nomor 8 Tahun 2012 tentang Pemilu Anggota DPR, DPD dan DPRD."

[26] "UU Nomor 11 Tahun 2006 tentang Pemerintahan Aceh."

[27] Howlett M. and M. Ramesh, Studying Public Policy. Policy Cycles and Policy Subsystems. Toronto: Oxford University Press, 1995.

[28] "UU Nomor 17 Tahun 2007 tentang Rencana Pembangunan Jangka Panjang 2005-2025."

[29] Muchsin H. and F. Putera, Hukum dan Kebijakan Publik. Malang: Averroes Press, 2002.

[30] LAN, "Arsitektur LNS, Definisi, Kriteria, dan Arahan Penataan Ke Depan," 2015. http://inovasi.lan.go.id/uploads/download/1452182781_Arsitektur-LNS-(PIKSA-LAN).pdf

[31] "UU Nomor 30 Tahun 2014 tentang Administrasi Pemerintahan."

[32] "UU Nomor 30 Tahun 2002 tentang Komisi Pemberantasan Korupsi."

[33] "UU Nomor 5 Tahun 2014 tentang Aparatur Sipil Negara."

[34] Henry N. Public Administration and Public Affairs. London: Prentice-Hall International, Inc, 1989.

[35] Siagian, S. P. Filsafat Administrasi, Edisi Revisi. Jakarta: Bumi Aksara, 2008.

[36] Surbakti, R. Memahami Ilmu Politik. Jakarta: PT. Gramedia Widiaswarana Indonesia, 1999.

[37] Harianti, R. et al. "Penerapan Prinsip Independensi dan Etika Bagi Penyelenggara Pemilu di Aceh Pada Penyelenggaraan Pemilu Tahun 2019,” Nusant. J. Ilmu Pengetah. Sos., vol. 6, no. 2, 2019. 
[38] Ardipandanto, A. "Permasalahan Penyelenggaraan Pemilu Serentak Tahun 2019. Pusat Pnelitian Badan Keahlian DPR RI. Info Singkat," Bid. Pemerintah. Dalam Negeri, vol. XI, no. 11///Puslit/Juni/2019, 2019.

[39] Puspitasari, C. D. A. et al. "Kinerja Bawaslu Ditinjau Dari Komitmen Organisasi, Etos Kerja dan Team Work," J. Bening, vol. 8, no. 1, 2021.

[40] Gusfa, H. et al. "Modelisasi Komunikasi Konstitutif Dewan Kehormatan Penyelenggara Pemilu Periode 2012-2017 berdasarkan Manajemen Pengetahuan,” J. Kaji. Komun., vol. 7, no. 1, 2019. 